\title{
Editorial:
}

\section{Where do cross disciplinary interests in educational research merge?}

\section{Dolana Mogadime}

Editor-in-chief

Brock University

Educational research maybe cross disciplinary but it merges in the interest to investigate and answer questions of importance to educational practitioners, researchers and students alike. This Brock Education Journal issue brings together research from across Canada, all of which increase appreciation for the rigor of research for informing and improving the educational experiences of learners, professional practices and the quality of education. Furthermore, the articles challenge perceived understandings and provide directives on finding enlighten new directions through the recommendations provided. In "A Commentary: Education in Canada—Does Anyone Read Our Constitution?" Ron Phillips sheds a light on how inequality in the provision of funds for First Nations-managed schools is systemic and deliberate. He does so by posing the key problematic: "These educational structures, programs and services are common throughout provincial and territorial systems. Why were they lacking in First Nations-managed schools and communities?" Phillips' explanation includes a rigorous conceptual analysis of two overarching causalities. Firstly, systemic inequity is rooted in the historical subjugation of Indigenous people, from a colonial legacy of discrimination. Secondly, due to misunderstandings about the Canadian Constitution, education is perceived to be neither the sole responsibility of the province nor the federal government but both. Philips analysis points to the consequences for these misunderstandings.

In "Professional Lives and Initial Teacher Education Experiences of Indigenous Early Childhood Educators, Childcare Workers, and Teachers in Northern Ontario," Shelley Stagg Peterson, Lori Huston and Roxanne Loon make known the sojourner paths that Indigenous Early Childhood Education (ECE) community leaders undergo in their desire to become credentialed. The stories the women tell, arising out of focus group testimonials make known to the heroines' journey they undertake. It is no small feat to claim an education and to lead their own communities, when accessing an education has personal scarifies, such as leaving one's family (located in remote Northern communities) to attend university at a distance. One can only have a growing sense of respect for the women who through attainting an education participate in the delivery of curriculum that is relevant to their own communities. Shelley Stagg Peterson, Lori Huston and Roxanne Loon's article dig deep into the complexity of Indigenous women's agency in the face of both obstacles and constraints they surmount on an ongoing basis.

In 'Chinese International Students' Sense of Belonging in North American Postsecondary Institutions: A Critical Literature Review," Jia Chen and George Zhou examine how educational institutions are responding to the growing number of international students in Canada who are citizens of China. Their review of the literature is timely and can be used by institutions to enhance an informed moral imperative to nurture the full potential and growth of all students. The researchers offer a critical review that pushes the boundaries by providing directives for 
educational institutions regarding their responsibilities for the students sense of well-being particularly as that sense is linked to student success.

In "Internalizing Cognitive Bias: An Experiential Exercise for Teaching and Learning the Anchoring Effect," John C. Kleefeld and Dionne Pohler share the results of their 7 year-long study involving 378 individuals and 19 classroom settings. The study focuses on supporting the ability among students to become good decision makers. With consideration of the professional importance of professional judgement among students in business, law, human resources, and public policy, the authors aim to impart deep knowledge about 'the anchoring effect.' A term described as, "a cognitive bias that causes decision-makers to rely too heavily on initial information when making subsequent judgments." The contribution of the research for professional students and instructors alike, include the innovated approaches to the examination of 'anchoring' thought processes that "enable quick decisions but also lead to perceptual distortions, inaccurate judgments, and illogical interpretations."

In "Teachers as Learners in the (Literal) Field: Results From an International Service Learning Internship," Daniel J. Robinson, Ingrid Robinson and Andrew Foran report on a novel study that investigated an international service learning internship for in-service teachers. As the researchers argue there is a burgeoning body of research on pre-service teachers engaged in internships but little to none on inservice educators. As researchers making inroads in this nuanced area of inquiry they have much to offer up in terms what can be gained as well as recommendations on next steps for researchers that who may take on a similar focused study.

In 'Novice Teachers' Perspectives on the Use of Languages in French as a Second Language Classes That Include English Language Learners," Callie Mady and Katy Arnett study focuses on three overarching questions: "1. How do novice teachers conceptualize language use in FSL classrooms with ELLs?; 2. Within novice teachers' thinking about how to support language learners, to what extent is another language a consideration?; 3. How do novice teachers consider the ELLs' home language as an influence on their experience with FSL?" The questions arise within the contexts of sparse studies, with one that demonstrated novice FSL teachers face challenges with the inclusion of ELLs in FSL classes. Recommendations from the study include suggestions to BEd teacher educators, that they "not only highlight the potential advantages of a plurilingual approach but also means" make known how to "put it into practice." Additionally, they argue that the Ministry of Education has a role to play in providing direction on "how to use other languages to support FSL acquisition." Overall, this issue challenges readers to reconceptualize perceived views on the topics investigated. As such the works offered up are a must read for researchers, practitioners and students across the disciplines in which the varied works are grounded.

\section{Editorial Postscript: “A Fond Farwell”}

This issue is the last in my tenure as Editor-in-Chief, like Julian Kitchen (2014) the past editor, I bid a "Fond Farewell." It has been an extortionary 5 years serving at the helm. To be granted this gift to serve colleagues throughout Canada and internationally is an unparalleled honor. Within such a leadership capacity, 7 journal issues were produced, 2 of which were co-edited with Special Issue Guest Editors. Furthermore, an additional 2 issues were published by colleagues who were Guest Editors. BEJ features 5 - 8 articles in each issue in a consistent manner. Over the past 3 years BEJ has gained further recognition as newly listed in Emerging Sources Citation Index (ESCI) within the Web of Science. ESCI is linked to a wider circulation of international readers. Hence, 
authors of BEJ gain greater visibility. I am also pleased that BEJ has been relisted with the Directory of Open Access Journals (DOAJ) and newly listed in the USA based - Education Resources Information Center ERIC in 2015. The three listings signal that BEJ produces quality, peer reviewed open access publications and is committed to contributing positively to the scholarly open access community.

In March 2015, with a grant from the Brock University Advancement Fund, a new website was developed with the assistance of David Genkin, IT Manager. The website has capabilities to feature YouTube videos for the journal. Over several months, I worked with David Potts, IT Project Manager to launch the 'Meet the Author' interview series. The readers of BEJ and the wider scholarly community are invited to view digital recorded interviews in the series that features BEJ authors in conversations about their writing and research interests. The "Meet the Author" series features a personal lens thorough which to understand the innovative writing and contributions of educational researchers. The goal of engaging wider audiences is achieved within an innovative face-to-face interview format. Most recently, the Brock University Open Access Award has contributed toward the journal publications in 2018 and 2019. The funding will continue to aid the funding of the next BEJ Special Issue. With this university-wide recognition of BEJ's role on the national and international scale, I hand BEJ to my trusted colleague, Trevor Norris. His extensive experience as journal editor, will bode BEJ well. I look forward staying connected to the journal by joining you, our loyal readers, as I delve into the treasure trove in educational research found in each issue.

Acknowledgment: BEJ is grateful for the generous funding provided through the Brock University Open Access Award, 2018.

\section{References}

Chen, J. and Zhou, G. (2019). Chinese International Students' Sense of Belonging in North American Postsecondary Institutions: A Critical Literature Review. Brock Education: A Journal of Educational Research and Practice, 28 (2), pp. 48-63.

Kitchen, J. (2014). Editorial: A fond Farewell. Brock Education: A Journal of Educational Research and Practice, 23 (2), 1-2.

Kleefeld, J. C., and Pohler, D. (2019). Internalizing Cognitive Bias: An Experiential Exercise for Teaching and Learning the Anchoring Effect. Brock Education: A Journal of Educational Research and Practice, 28 (2), 33-47.

Mady, C., and Arnett, K. (2019). Novice Teachers' Perspectives on the Use of Languages in French as a Second Language Classes That Include English Language Learners. Brock Education: A Journal of Educational Research and Practice, 28 (2), 82-95.

Peterson, S. S., Huston, L., and Loon, R. (2019). Professional Lives and Initial Teacher Education Experiences of Indigenous Early Childhood Educators, Childcare Workers, and Teachers in Northern Ontario. Brock Education: A Journal of Educational Research and Practice, 28 (2), 17-32.

Phillips, R. (2019). A Commentary: Education in Canada-Does Anyone Read Our Constitution? Brock Education: A Journal of Educational Research and Practice, 28 (2), 4-16.

Robinson, D., Robinson, I., and Foran, A. (2019). Teachers as Learners in the (Literal) Field: Results from an International Service Learning Internship. Brock Education: A Journal of Educational Research and Practice, 28 (2), 64-81. 